\title{
PRINCETON \\ ENCYCLOPEDIA \\ OF POETRY AND POETICS
}




\section{PRINCETON}

\section{ENCYGLOPEDIA}

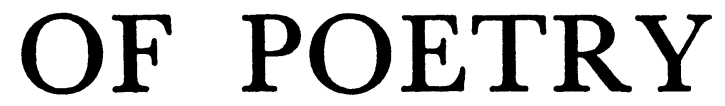

AND POETICS

\section{ALEX PREMINGER}

\section{EDITOR}

FRANK J. WARNKE AND O. B. HARDISON, JR.

ASSOCIATE EDITORS

Enlarged Edition

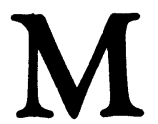




\title{
TO
}

\section{AUGUSTA FRIEDMAN PREMINGER}

\author{
(C) 1965, Enlarged Edition (C) 1974, \\ Princeton University Press \\ Softcover reprint of the hardcover 1st edition 1974
}

All rights reserved. No part of this publication may be reproduced or transmitted, in any form or by any means, without permission.

\section{Enlarged Edition}

First published in the United States 1975

First published in the United Kingdom 1975

Published by

THE MACMILLAN PRESS LTD

London and Basingstoke

Associated companies in New York

Dublin Melbourne Johannesburg and Madras

ISBN 978-0-333-18121-8 ISBN 978-1-349-15617-7 (eBook)

DOI 10.1007/978-1-349-15617-7 


\section{PREFACE}

The ENCYCLOPEDIA OF POETRY AND POETICS is the most comprehensive treatment of its field yet attempted. It consists of about 1,000 individual entries ranging from twenty to more than 20,000 words, dealing with the history, theory, technique, and criticism of poetry from earliest times to the present. The entries are designed to be useful to the general reader, the student, and the professional scholar. They are supplemented by substantial bibliographies and generous cross-references.

Articles on individual authors, poems, and allusions have been excluded from the ENCYCLOPEDIA as readily available in other reference works. Otherwise, the policy of the editors has been to avoid arbitrary limitations. The danger of too narrow a definition of "poetry" has been recognized, and the reader will find numerous articles dealing with the area between prose and poetry (e.g., VERSE AND PROSE, PROSE POEM, PROSE RHYTHM, FREE VERSE), and topics equally relevant to prose and poetry (e.g., PLOT, MYTH, SYMBOL, IMAGERY). Of particular interest in view of the renaissance of literary criticism in the twentieth century are the numerous articles dealing with poetic theory, schools of criticism, and critical terms. Current interest in poetics also informs many of the entries dealing with the history and forms of poetry.

The entries in the ENCYCLOPEDIA are arranged in alphabetical order. However, they may be grouped under four general headings: (I) History of Poetry; (II) Techniques of Poetry; (III) Poetics and Criticism; (Iv) Poetry and its Relationship to Other Fields of Interest.

(I). The history of poetry is treated in terms of languages, movements, and schools. The reader will find entries on the history of each of the major bodies of world poetry-English, American, French, Indian, Arabic, Japanese, etc.-as well as shorter entries on such minor bodies of poetry as Korean poetry, Yiddish poetry, American Indian poetry, and Eskimo poetry. Movements which cut across linguistic or national boundaries are treated in articles such as RENAISSANCE POETRY, ROMANTICISM, and SYMBOLISM. Shorter articles deal with movements or schools peculiar to one country (e.g., DOLCE STIL NUOVO, PRE-RAPHAELITE BROTHERHOOD, PLÉIADE). In every case the aim has been to provide a coherent summary of the important facts illustrated by frequent citations, together with the critical evaluation necessary to an intelligent understanding of the subject.

(II). Technique is covered in articles on STYLE, POETIC DICTION, IMAGERY, RHYME, and the like. There is a general article on FIGURES

$$
\text { -[ v ] }
$$




\section{PREFACE}

OF SPEECH, as well as articles on specific figures like METAPHOR, sIMILE, and concerr. The more important terms of traditional rhetoric are included along with terms which have become current through the influence of modern criticism. The sound values of poetry are treated in SOUND IN POETRY, and in shorter entries on TONE COLOR, ONOMATOPOEIA, ALLITERATION, ASSONANCE, and the like. The major genres, such as tragedy, epic, and lyric, receive extended treatment in terms of both history and theory. More general forms (e.g., DRAMATIC POETRY, NARRATIVE POETRY) are discussed in separate articles, as are such rarely treated subjects as EROTIC POETRY and ORAL POETRY.

Prosody is treated in a general article as well as in more specific entries on ClASSICAL PROSODY, ENGLISH PROSODY, ROMANCE PROSODY, SLAVIC PROSODY, and CELTIC PROSODY, to name only a few. A general article on METER is supplemented by entries on such conventional "types" as heXameter, heroic couplet, and elegiac distich. Special care has been taken to provide adequate representation for techniques and prosodic forms common in non-Western poetry, e.g., haiku, GHASEl, and sloka.

(III). Poetics and criticism receive special emphasis in the ENCYCLOPEdia. Poetics is treated most generally in POETICs, concePtions OF and POETRY, THEORIES OF. These are supplemented by entries dealing with classical poetics, medieval poetics, Neoclassical POETICS, MODERN POETICS, etc. In addition, the discussions of major literary movements, schools, and genres deal extensively with theory.

The types, objectives, and problems of criticism are explained in CRITICISM, TYPES OF and CRITICISM, FUNCTION OF. They are explored in greater detail in entries on ANALYSIS, EXPLICATION, EVALUATION, and the like. A great many critical terms are discussed separately; e.g., IMAGINATION, FANCY, CONCRETE UNIVERSAL, INVENTION, DECORUM, IMITATION, OBJECTIVE CORRELATIVE, AMBIGUITY, TENSION.

(Iv). The relationship of poetry to other fields of interest is examined in articles such as FINE ARTS AND POETRY, MUSIC AND POETRY, PHILOSOPHY AND POETRY, RELIGION AND POETRY, and SOCIETY AND POETRY.

The guiding policies of the editors of the ENCYCLOPEDIA have been accuracy, utility, interest, and (within necessary space limitations) thoroughness. Our contributors have been selected because of recognized excellence in their fields, and we have intentionally refrained from the attempt to impose a preconceived, uniform point of view on their contributions. Each author has been encouraged to present his material in terms of the approach which he feels to be most appropriate. The result is a variety of points of view, representative of the best modern criticism and scholarship. In the opinion of the editors, anything less would be unfair to both readers and contributors. 


\section{PREFACE}

Two nonsubstantive types of revision have been made by the editors in preparing the manuscript of the ENCYCLOPEDIA for the printer.

(1) Abbreviations have been used throughout in the interests of brevity and consistency of format. As in several continental reference works, the entry word of an article has been abbreviated to its first letter (or letters) when it recurs in the text of the article. Thus imagery is abbreviated in the text of that article by i.; satire by s.; and so forth. Common abbreviations (c. for century [ies]), Gr. for Greek, etc.) have been used freely. Finally, authors and works referred to frequently throughout the ENCYCLOPEDIA are abbreviated by one or two key words. Full citations of these bibliographic references will be found in the LIST of abBreviations on Page xvi.

(2) Forms of citations, conventions of capitalization, use of italics (e.g., for titles of poems), and the like have been standardized where possible for the sake of consistency.

The ENCYCLOPEDIA OF POETRY AND POETICS has been a cooperative undertaking. It has been made possible only through the learning, dedication, and effort of the contributors. To them the editors wish to extend sincere and warm thanks. A special word of appreciation is due William Arrowsmith, Palmer Bovie, Alfred G. Engstrom, Alvin Eustis, Jr., Paul Fussell, Jr., the late Robert J. Getty, Ulrich K. Goldsmith, Fabian Gudas, Murray Krieger, David I. Masson and Roy Arthur Swanson; as well as M. H. Abrams, George Arms, John Arthos, Paull F. Baum, Max I. Baym, Jess B. Bessinger, Frank M. Chambers, Dorothy Clotelle Clarke, Procope S. Costas, R. S. Crane, Fred A. Dudley, Charles W. Dunn, John J. Enck, Victor Erlich, Robert O. Evans, Solomon Fishman, Wolfgang Bernhard Fleischmann, Richard H. Fogle, Ralph Freedman, Albert B. Friedman, Norman Friedman, Joseph G. Fucilla, Samuel Hazo, Hanford Henderson, Roger A. Hornsby, W. T. H. Jackson, Charles W. Jones, John R. Krueger, Craig La Drière, R.-F. Lissens, Sverre Lyngstad, Clarence A. Manning, Vladimir Markov, Robert Marsh, Earl Miner, Luis Monguió, G. N. G. Orsini, Laurence Perrine, Allen W. Phillips, Seymour M. Pitcher, F. J. E. Raby, Brewster Rogerson, Aldo Scaglione, H. Stefan Schultz, Christoph E. Schweitzer, V. Setchkarev, A. J. M. Smith, Kiril Taranovski, Kurt Weinberg, Philip Wheelwright, A. S. P. Woodhouse, and Lawrence J. Zillman, whose help went beyond the boundaries of their signed contributions. Several scholars, it should be appreciatively acknowledged, also assumed the responsibility for completing or updating the articles of colleagues who had died while the ENCYCLOPEDIA was still in progress.

We are grateful, too, to the following scholars, critics, and poets who are not among our contributors but who have generously given us their advice, specific suggestions, and criticisms: Alfred Adler, 


\section{PREFACE}

Brooklyn College; Sverre Arestad, University of Washington; Hayden Clair Bell, University of California (Berkeley); Armando Correia Pacheco, Pan American Union; Joseph F. de Simone, Brooklyn College; S. Dinamarca, Brooklyn College; David Djaparidze, Princeton University; David M. Dougherty, University of Oregon; Samuel H. Elbert, University of Hawaii; David C. Fowler, University of Washington; Marcel Françon, Harvard University; Thomas Greene, Yale University; Henry Hatfield, Harvard University; Gilbert Highet, Columbia University; Edwin Honig, Brown University; Langston Hughes; Lawrence Hyman, Brooklyn College; Ivar Ivask, St. Olaf College; S. F. Johnson, Columbia University; Walter Johnson, University of Washington; François Jost, University of Fribourg; Adolf D. Klarmann, University of Pennsylvania; Victor Lange, Princeton University; Wallace Lipton, Brooklyn College; Richard A. Long, Morgan State College; Roy MacNab; Percy Matenko, Brooklyn College; Fritz Mautner, Bryn Mawr College; Davidson Nicol, University College of Sierra Leone; Charles Passage, Brooklyn College; Daniel W. Patterson, University of North Carolina; Omeljan Pritsak; Guenther Rimbach, University of California (Riverside); D. W. Robertson, Jr., Princeton University; Alexander Rodger, Edinburgh University; Louis Schoffman, Brooklyn College; Thomas A. Sebeok, Indiana University; Stavro Skendi, Columbia University; Arnold Stein, University of Washington; Claude Vigée, Brandeis University; Eliseo Vivas, Northwestern University; Robert Vlach, University of Oklahoma; Ernst Waldinger, Skidmore College; Ronald N. Walpole, University of California (Berkeley); Sigfried Wenzel, University of North Carolina; Maria Widnäs, University of Oklahoma; and Mary Yiu, Brooklyn College.

We are very much indebted also to Antoinette Ciolli, Brooklyn College Library, Martin Fine, Nicole Stern, Pamela Williams, Jean-Claude Preminger, Toby Preminger, and Tamara Arney for assisting in the preparation of the manuscript.

It remains to thank the Bollingen Foundation without whose aid this book could not have been completed at this time; Mr. Herbert S. Bailey, Jr., director of the Princeton University Press, for his understanding and support; and Mrs. James Holly Hanford, Princeton University Press editor, for her devoted and inspired help.

Flushing, New York

December 1963

THE EDITORS 


\section{PREFACE TO THE}

\section{ENLARGED EDITION}

In the first edition of this work the editors committed themselves to an ideal of comprehensiveness, hoping to make the Encyclopedia of Poetry and Poetics the most complete and accurate reference source of its kind. Nevertheless, there were inevitable oversights. No separate entries were provided for a number of important movements in poetry (HARLEM RENAISSANCE), major aspects of literature (THEME), and perennial issues (CENSORSHIP). The Supplement of about 75,000 words to this new edition of the Encyclopedia attempts to rectify such omissions, and it also includes dozens of other new entries that reflect recent developments in poetry and poetics.

Poetry, like any art, is in a constant process of change, and in the nine years since the publication of this Encyclopedia there have been many significant shifts in poetic practice and in the intellectual and social world that surrounds the poet's art. Accordingly, the Appendix includes such entries as ROCK LYRIC and COMPUTER POETRY, as well as an overview of contemporary AMERICAN POETIC SCHOOLS AND TECHNIQUES. Moreover, the increased cultural awareness and articulateness of ethnic minorities and emergent nations has required treatment here of such subjects as recent BLACK POETRY in the United States, PUERTo RICAN POETRY, and AFrICAN POETRY in various languages.

Many articles in the Appendix also call attention to recent developments in poetic criticism. An essay on METACrITICISM critically examines criticism itself. Such entries as STRUCTURALISM, PHENOMENOLOGY, and the GENEVA SCHOOL deal with ideas and movements which have proved themselves during the last decade to be of value in the study of literature. Fresh debate over traditional issues is summarized and analyzed in the treatments of HISTORICISM and INTERPRETATION. And new emphases in disciplines ancillary to literature are accounted for in such articles as PSYCHOLOGY AND POETRY and POLITICS AND POETRY.

The editors have again attempted to avoid construing "poetry and poetics" in either too inclusive or too narrow a fashion. They have not tried to encompass the whole area of imaginative literature: such an effort would have resulted in an unwieldy work of many volumes. Instead, they have restricted the province of the Princeton Encyclopedia of Poetry and Poetics to metrical or quasi-metrical composition, hoping to maintain a clear unity of subject matter. On the other hand, the editors have included some topics (e.g., articles 


\section{PREFACE TO THE ENLARGED EDITION}

on criticism or on general literary techniques) which apply to prose as well as to poetry. Moreover, they have made no effort to rule out occasional references to prose works in the entries. As in the first edition, the editors have adopted the policy of entrusting the articles to authorities recognized in their respective fields, and of allowing these contributors considerable freedom in point of view and development.

The editors owe a special debt of gratitude to the following contributors, past and present, for advice, concrete suggestions, and criticisms: Monroe C. Beardsley, David F. Dorsey, Paul Fussell, Fabian Gudas, Lyndon Harries, Kevin Kerrane, Murray Krieger, Sally N. Lawall, Sverre Lyngstad, Wallace Martin, Earl Miner, and Aldo Scaglione.

We should also like to thank: M. H. Abrams, Joseph G. Beaver, Seymour Chatman, Jonathan Culler, Paul de Man, Alvin Eustis, Bernard Wolfgang Fleischmann, Z. Folejewski, Ralph Freedman, Ulrich K. Goldsmith, John Hollander, Douglas Johnson, Samuel R. Levin, Richard A. Long, Louis Monguio, and Barbara Herrnstein Smith.

Various scholars, whose names do not appear in the List of Contributors, have assisted us by careful reading and helpful criticism of entries. We are grateful to: Barry Beckham (Brown University), Wilfred Cartey (Brooklyn College, City University of New York), Marshall Cohen (Graduate Center, City University of New York), Thomas Conley (University of California, Berkeley), Thomas R. Edwards (Rutgers University), Michael Fahey (University of Delaware), Mary Ann Geissal (Northeastern Illinois University), Albert S. Gérard (University of Liège), Norman N. Holland (State University of New York, Buffalo), Nathan Irvin Huggins (Columbia University), F. R. Jameson (University of California, San Diego), David Kalstone (Rutgers University), Edward Maxwell (Northeastern Illinois University), J. Hillis Miller (Yale University), Gerald Moore (University of Sussex), Gerald M. Moser (Pennsylvania State University), Edgar C. Polomé (University of Texas), Anthony Z. Romano (University of Delaware), Don Weller (University of Hawaii), and Carl Woodring (Columbia University).

Special thanks go again to Mrs. James Holly Hanford, our very able and dedicated Princeton University Press editor. 


\section{ACKNOWLEDGMENTS}

Great care has been taken to trace all the owners of copyright material used in this book. If any have been inadvertently overlooked or omitted, acknowledgment will gladly be made in any future editions.

Thanks are due to the following authors, publishers, and representatives who have so courteously granted permission to use selections from copyrighted publications.

The Africana Publishing Corporation for six lines of "Heavensgate" reprinted from Labyrinths by Christopher Okigbo, copyright 1971 by Legal Personal Representatives of Christopher Okigbo, by permission of Africana Publishing Corporation.

The Bernice P. Bishop Museum for a nature poem, "Moolelo o Hawaii," manuscript by S. M. Kamakau, translated by M. W. Beckwith and M. K. Pukui.

William Blackwood \& Sons, Ltd., Hugh MacDiarmid, and The Macmillan Co. for six lines of "The Bonnie Broukit Bairn" from The Collected Poems of Hugh MacDiarmid, copyright 1948, 1962 by Christopher Murray Grieve.

The Bodley Head, Ltd., for four lines by Fedor Tyutchev, from Modern Russian Poetry. An Anthology. Chosen and translated by Babette Deutsch and Avrahm Yarmolinsky.

Cambridge University Press, for twelve lines, from Literary History of the Arabs by R. A. Nicholson, $2 \mathrm{~d}$ ed.

Clarendon Press, Oxford, for the first eight lines of "Cheddar Pinks," from the Poetical Works of Robert Bridges. Excluding the Eight Dramas.

Editions Gallimard, for four lines by Paul Valéry from La Jeune Parque, copyright 1917 by Editions Gallimard, and three lines by Paul Valéry from Charmes, copyright 1922 by Editions Gallimard.

Faber and Faber, Ltd., for first stanza of "September 1, 1939," from Collected Shorter Poems by W. H. Auden; for excerpts from 


\section{ACKNOWLEDGMENTS}

Poetic Diction: A Study in Meaning by Owen Barfield, new ed. 1952; for three lines of "Ash Wednesday," from Collected Poems by T. S. Eliot.

Farrar, Straus and Cudahy, for excerpts from The Heresy of Courtly Love by A. J. Denomy.

Grove Press, for "Oread," from Selected Poems by H. D., copyright 1957 by Norman Holmes Pearson.

Harcourt, Brace \& World, Inc. for three lines of "Ash Wednesday," from Collected Poems of T. S. Eliot, copyright 1936 by Harcourt, Brace \& World, Inc.

Harcourt Brace Jovanovich, Inc., for the poem "l(a" by E. E. Cummings. Copyright 1958 by E. E. Cummings. Reprinted from his volume Complete Poems 1913-1962 by permission of Harcourt Brace Jovanovich, Inc.

Harvard University Press, for excerpts from Aristotle, The Poetics; "Longinus," On the Sublime; Demetrius, On Style, Loeb Classical Library.

Heinemann Educational Books, Ltd., for four lines of "The sounds begin again" from A Simple Lust by Dennis Brutus and for six lines of "Heavensgate" from Labyrinths with Path of Thunder by Christopher Okigbo. These lines reprinted by permission of the publishers, Heinemann Educational Books Ltd., London.

Hill and Wang, for four lines of "The sounds begin again" from A Simple Lust by Dennis Brutus. Reprinted with the permission of Hill and Wang, a division of Farrar, Straus \& Giroux, Inc. Copyright 1963, 1968, 1970, 1971, 1973 by Dennis Brutus.

Holt, Rinehart and Winston, Inc., for "The Golf Links Lie So Near the Mill," from Portraits and Protests by Sarah N. Cleghorn. All rights reserved. Reprinted by permission of Holt, Rinehart and Winston, Inc.

Houghton Mifflin Co., for four lines of "Ars Poetica," from Collected Poems, 1917-1952 by Archibald MacLeish, reprinted by permission and arrangement with Houghton Mifflin Co. Copyright 1952 by Archibald MacLeish; for "Lilacs," from Complete Poetical Works of Amy Lowell. Copyright 1955 by Houghton Mifflin Co.

The Irish Texts Society, for lines from Aithdioghluim Dana, edited by L. McKenna. 


\section{ACKNOWLEDGMENTS}

Alfred A. Knopf, Inc., for first four lines of "Planting Bamboos" by Po-Chüi, from Translations from the Chinese, by Arthur Waley.

Little, Brown \& Co., for lines from "If I can stop one heart from breaking," from The Complete Poems of Emily Dickinson, edited by Thomas H. Johnson.

The Macmillan Company, for six lines of "The Bonnie Broukit Bairn," from The Collected Poems of Hugh MacDiarmid, copyright 1948, 1962 by Christopher Murray Grieve; for lines from The King of the Great Clock Tower, The Collected Plays of W. B. Yeats, 1952, 1953; for one line of "After Long Silence," the epigram "On Those that Hated 'The Playboy of the Western World,' 1907," four lines of "Sailing to Byzantium," four lines of "Under Ben Bulben V," eight lines of "Why Should Not Old Men Be Mad?" all from The Collected Poems of W. B. Yeats, definitive edition, 1956.

The Mediaeval Academy of America, for excerpts from A. J. Denomy, "Courtly Love and Courtliness," Speculum, 28 (1953), 44.

New Directions, for third stanza of "To a Friend," translated by Babette Deutsch, from Selected Writings by Boris Pasternak; for fifth stanza of "Apparuit," from Personae by Ezra Pound, copyright 1926, 1954 by Ezra Pound; for opening sentence from Under Milk Wood by Dylan Thomas, copyright 1954 by New Directions. Reprinted by permission of New Directions.

Oliver \& Boyd, Ltd. and the Trustees of the Alexander Carmichael estate, for second stanza of "Lament for Seathan," from Carmina Gadelica, compiled and translated by Alexander Carmichael.

Random House, Inc., for first stanza of "September 1, 1939," from Collected Poetry of W. H. Auden, copyright 1945 by W. H. Auden. For excerpt from Ulysses by James Joyce, copyright 1914, 1918 and renewed 1942, 1946 by Nora Joseph Joyce. Reprinted by permission of Random House, Inc.

Charles Scribner's Sons, for excerpt from an Inca prayer, from Ancient Civilization of the Andes by Philip Ainsworth Means, copyright 1931 Charles Scribner's Sons, renewal copyright 1959 Louise Muntoe Means, reprinted with the permission of Charles Scribner's Sons; for four lines of "America For Me," from Poems by Henry van Dyke.

Speculum, The Editors, for excerpts from A. J. Denomy, "Courtly Love and Courtliness," Speculum, 28 (1953), 44. 


\section{ACKNOWLEDGMENTS}

Stanford University Press, for the following selections in translation: five lines each by Hitomaro, Okura, Akahito, Narihira, Komachi, Yoshitada, Izumi Shikibu, Anon., Yoshitsune, Saigyō, Shunzei, Teika, Tamehide, ex-Empress Eifuku; ten lines by exEmperor Hanazono and three lines by Bashō, from Japanese Court Poetry, by Robert H. Brower and Earl Miner, copyright 1961 by the Board of Trustees of the Leland Stanford Junior University.

University of Chicago Press, for lines from Greek Lyrics, translated by Richmond Lattimore, copyright 1955 by Richard Lattimore.

Twayne Publishers, Inc., for six lines of "If we must die," from Selected Poems of Claude McKay.

University of Wales Press, for lines 668-673 from Canu Aneirin, edited by Ifor Williams.

A. P. Watt and Son, Mrs. W. B. Yeats, the Macmillan Co. of Canada Ltd., and Messrs. Macmillan \& Co. Ltd., for lines from The King of the Great Clock Tower, The Collected Plays of W. B. Yeats, 1952, 1953; for one line of "After Long Silence," the epigram "On Those that Hated 'The Playboy of the Western World,' 1907," four lines of "Sailing to Byzantium," four lines of "Under Ben Bulben V," eight lines of "Why Should Not Old Men Be Mad?" all from The Collected Poems of W. B. Yeats, definitive edition, 1956. 


\section{CONTENTS}

$\begin{array}{lr}\text { PREFACE TO FIRST EDITION } & \mathbf{v} \\ \text { PREFACE TO ENLARGED EDITION } & \text { ix } \\ \text { ACKNOWLEDGMENTS } & \mathbf{x i} \\ \text { ABBREVIATIONS, BIBLIOGRAPHICAL } & \mathbf{x v} \\ \text { ABBREVIATIONS, GENERAL } & \mathrm{xix} \\ \text { CONTRIBUTORS } & \mathbf{x x} \\ \text { PRINCETONENCYCLOPEDIA OF POETRY } & \\ \text { AND POETICS } & 3 \\ \text { SUPPLEMENT } & 909\end{array}$




\section{LIST OF ABBREVIATIONS}

\section{BIBLIOGRA P H ICAL}

Abrams M. H. Abrams, The Mirror and the Lamp. Romantic Theory and the Critical Tradition, 1953.

AJP American Journal of Philology

AL American Literature

ASch American Scholar

ASEER American Slavic and Eastern European Review

ASR American-Scandinavian Review

Auc Anales de la Universidad de Chile

Auerbach E. Auerbach, Mimesis. The Representation of Reality in Western Literature, tr. W. R. Trask, 1953.

BA Books Abroad

Baum P. F. Baum, The Principles of English Versification, 1922.

Beare W. Beare, Latin Verse and European Song, 1957.

Behrens I. Behrens, Die Lehre von der Einteilung der Dichtkunst (Beihefte zur Zeitschrift für Romanische Philologie, 92, 1940).

BHR Bibliothèque d'humanisme et renaissance

Bowra C. M. Bowra, Greek Lyric Poetry from Alcman to Simonides, 1936, 2d ed., 1961.

Bray R. Bray, La Formation de la doctrine classique en France, 1927.

Brooks and Warren C. Brooks and R. P. Warren, Understanding Poetry, 2d ed., 1950, 3d ed., 1960.

Brooks, Tradition C. Brooks, Modern Poetry and the Tradition, 1939.

Bz Byzantinische Zeitschrift (Leipzig)

Cabeen A Critical Bibliography of French Literature, general ed. D. C. Cabeen, 1- ; 1947- (in progress).

Cassell's Cassell's Encyclopaedia of World Lit. erature, ed. S. H. Steinberg, 2 v., 1954.

CBEL Cambridge Bibliography of English Literature

CE College English

Chadwick H. M. and N. K. Chadwick, The Growth of Literature, 3 v., 1932-40.

CHEL Cambridge History of English Litera. ture

c. Comparative Literature

CP Classical Philology

C.Q Classical Quarterly

Crane R. S. Crane, The Languages of Criti. rism and the Structure of Poetry, 1953.
Crane, Critics Critics and Criticism, Ancient and Modern, ed. R. S. Crane, 1952.

Crusius F. Crusius, Römische Metrik, 2d ed., 1955.

Curtius E. Curtius, European Literature and the Latin Middle Ages, tr. W. R. Trask, 1953.

Cw Classical World

Daiches D. Daiches, Critical Approaches to Literature, 1956.

Dale A. M. Dale, The Lyric Metres of Greek Drama, 1948.

- Deutsch B. Deutsch, Poetry Handbook, 1957, 2d ed., 1962.

DVLG Deutsche Vierteljahrsschrift für Literaturwissenschaft und Geistesgeschichte

Ess Essays and Studies by Members of the English Association

EIC Essays in Criticism (Oxford)

EIE English Institute Essays

Eliot, Essays T. S. Eliot, Selected Essays, 1932, rev. ed., 1950.

Eliot, Wood T. S. Eliot, The Sacred IVood: Essays on Poetry and Criticism, 1920.

Empson W. Empson, Seven Types of Ambiguity, 1930, 2d ed., 1947.

FiR Filologia romanza

FM Français moderne

Frye N. Frye, Anatomy of Criticisın, 1957.

Fs French Studies

Gayley and Kurtz C. M. Gayley and B. P. Kurtz, Methods and Materials of Literary Criticism: Lyric, Epic and Allied Forms of Poetry, 1920.

Gilbert and Kuhn K. Gilbert and $H$. Kuhn, A History of Esthetics, 1939, 2d ed., 1953.

Hamer E. Hamer, The Metres of English Poetry, 1930.

Hardie W. R. Hardie, Res metrica, 1920.

HR Hispanic Review

HSCL Harvard Studies in Comparative Literature

HscP Harvard Studies in Classical Philology HsS Harvard Slavic Studies

JAAC Journal of Aesthetics and Art Criticism JAF Journal of American Folklore

Jeanroy A. Jeanroy, I.a Poésie lyrique des troubadours, 2 v., 1934. 


\section{ABBREVIATIONS}

Jeanroy, Origines A. Jeanroy, Les Origines de la poésie lyrique en France au moyen dge, 3d ed., 1925.

JEGP Journal of English and Germanic Philology

JHI Journal of the History of Ideas

JNH Journal of Negro History

JwcI Journal of the Warburg and Courtauld Institute

Kastner L. E. Kastner, A History of French Versification, 1903.

Ker W. P. Ker, Form and style in Poetry, 1928.

Koláf A. Koláł, De re metrica poetarum Graecorum et Romanorum, Prague, 1947.

Koster W. J. W. Koster, Traité de métrique grecque suivi d'un précis de métrique latine, 2d ed., Leyden, 1953.

KR Kenyon Review

Krieger M. Krieger, The New Apologists for Poetry, 1956.

Langer S. K. Langer, Philosophy in a New Key, 1948.

Lausberg H. Lausberg, Handbuch der literarischen Rhetorik, 2 v., 1960.

Lehmann A. G. Lehmann, The Symbolist Aesthetic in France, 1885-95, 1950..

Lewis C. S. Lewis, The Allegory of Love, 1936.

LonM London Magazine

Martino P. Martino, Parnasse et symbolisme, 1850-1900, 1925, 4th ed., 1935.

$M d F$ Mercure de France

MLF Modern Language Forum

MLJ Modern Language Journal

MLN Modern Language Notes

MLQ Modern Language Quarterly

MLR Modern Language Review

Morris-Jones J. Morris-Jones, Cerdd Dafod, 1925.

MP Modern Philology

N\&Q Notes and Queries

Navarro T. Navarro, Métrica española: Reseña histórica y descriptiva, 1956.

NED New English Dictionary

Neophil Neophilologus (Groningen)

Nicoll A. Nicoll, $A$ History of English Drama, 1660-1900, 6 v., 1952-59.

Norden E. Norden, Die antike Kunstprosa, 5th ed., 2 v., 1958.

OED Oxford English Dictionary

OsP Oxford Slavonic Papers

Parry T. Parry, A History of IT'elsh Literature, tr. H. I. Bell, 1955.

Patterson W. F. Patterson, Three Centuries of French Poetic Theory, 3 v., 1935.

PMLA Publications of the Modern Language Association of America

PQ Philological Quarterly

PR Partisan Rcview

QQ Queen's Quarterly

QR Quarterly Review
Raymond M. Raymond, De Baudelaire au surréalisme, 1933, 2d ed., 1940.

Reallexikon Reallexikon der deutschen $\mathrm{L} i$ teraturgeschichte, ed. P. Merker and W. Stammler, 4 v., 1925-81; 2d ed., ed. W. Kohlschmidt and W. Mohr, 1958- (in progress).

Ren Renascence

RES Review of English Studies

RF Romanische Forschungen

RFE Revista de filologia española

RHL Reuue d'histoire littéraire de la France

Richards, Practical I. A. Richards, Practical Criticism, 1929.

Richards, Principles I. A. Richards, Prin. ciples of Literary Criticism, 1925.

RLC Revue de littérature comparée

RLR Revue des langues romanes (Montpellier)

Rom Romania

RPh Roman Philology

Saintsbury G. Saintsbury, History of Criticism and Literary Taste in Europe, 3 v., 1900-04.

Saintsbury, Prosody G. Saintsbury, A History of English Prosody, 3 v., 1906-10.

SAQ South Atlantic Quarterly

SAww Sitzungsberichte der [österreichischen] Akademie der Wissenschaften in Wien. Phil.hist. Klasse

SB Studies in Bibliography: Papers of the Bibliographical Society of the University of Virginia

Schipper J. M. Schipper, Englische Metrik, 3 v., 1881-1888 (abridged and tr. as $A$ History of English Versification, 1910).

Schmid and Stählin W. Schmid and O. Stählin, Geschichte der griechischen Literatur, 2 v., $1929-48$.

Science and Literature International Federation for Modern Languages and Literatures. Literature and Science. Proceedings of the Triennial Congress held at Oxford 1954, 1956.

SD Studi danteschi

SEER Slavonic and East European Review [title changed to: Slavic Review]

SFI Studi di filologia italiana

Shipley Dictionary of World Literature, ed. J. T. Shipley, 1943, rev. ed., 1953.

ShS Shakespeare Survey

Smyth H. W. Smyth, Greek Melic Poets, 1906. SOED Shorter Oxford English Dictionary

SP Studies in Philology

sQ Shakespeare Quarterly

SR Sewanee Review

SRen Studies in the Renaissance

Sutton W. Sutton, Modern American Criticism, 1963.

SWR Southwest Review

Sym Symposium

TLS [London] Times Literary Supplement

TPAPA Transactions and Proceedings of the American Philological Association 


\section{ABBREVIATIONS}

TPs Transactions of the Philological Society (London)

TsE Tulane Studies in English

Tuve R. Tuve, Elizabethan and Metaphysical Imagery, 1947.

Uncsca University of North Carolina Studies in Comparative Literature

UNCsinL University of North Carolina Studies in the Romance Languages and Literatures UTsE University of Texas Studies in English Weinberg B. Weinberg, A History of Literary Criticism in the Italian Renaissance, 2 v., 1961.

Wellek R. Wellek, $A$ History of Modern Criticism, 1750-1950, 1955- (in progress).

Wellek and Warren $R$. Wellek and $A$. Warren, Theory of Literature, 1949, 2d ed., 1956.

Wheelwright P. Wheelwright, The Burning
Fountain. A Study in the Language of Symbolism, 1954.

Wilkins E. H. Wilkins, A History of Italian Literature, 1954.

Wilson E. Wilson, Axel's Castle, 1931.

Wimsatt W. K. Wimsatt, Jr. and M. C. Beardsley, The Verbal Icon, 1954.

Wimsatt and Brooks W. K. Wimsatt, Jr. and C. Brooks, Literary Criticism: A Short History, 1957.

WR Western Review

Ycs Yale Classical Studies

YFs Yale French Studies

ZDP Zeitschrift für deutsche Philologie

ZRP Zeitschrift für romanische Philologie

ZSP Zeitschrift für slavische Philologie

zvs Zeitschrift für vergleichende Sprachforschung 


\section{LIST OF ABBREVIATIONS GENERAL}

\author{
Am. American \\ anthol. anthology \\ aseoc. association \\ b. born \\ bibliog. bibliography \\ c. century; centurics \\ ca. about \\ cf. confer, compare \\ ch. chapter \\ cl. classical; classicism \\ crit. critical; criticism \\ d. died \\ dict. dictionary \\ diss. discertation \\ ed. editor; edited (by); edition \\ e.g. exempli gratia, for example \\ Eng. Engliah \\ enl. enlarged \\ et al. et alii, and others \\ f. following \\ f. floruit, flourished \\ fr., frag. fragment \\ Fr. French \\ Geach. Geschichte \\ Gr. Greek \\ hist. history, histoire \\ i.e. id est, that is \\ introd. introduction \\ Ir. Iriah \\ It. Italian
}

jour. journal

L. Latin

lit. literature (s); literary

LL Late Latin

loc. cit. loco citato, in the place cited

ME Middle English

ms(s) manuscript(s)

$O E$ Old English

OF Old French

ON Old Norse

p., pp. page; pages

pr. printed

prep. preparation

proc. proceedings

Prov. Provençal

publ. published

q.v. quod vide, which see

qq.v. quae vide, both which, or all which, see

Ren. Renaissance

repr. reprint; reprinted

rev. revised

Rus. Russian

8. siècle

sc. scilicet, to wit

Sp. Spanish

supp. supplement; supplementary

t. tome

tr. translated by; translation (s)

- An asterisk at the end of a word or phrase indicates that an entry on this subject will be found in the Supplement. 


\section{THE CONTRIBUTORS}

Kenneth M. Abbott, Professor of Classical Languages, Ohio State University

M. H. Abrams, Frederic T. Whiton Professor of English, Cornell University

Fernando Alegría, Professor of Spanish and Portuguese, Stanford University

Robert P. apRoberts, Professor of English, San Fernando Valley State College

Arthur J. Arberry, late Sir Thomas Adams's Professor of Arabic, University of Cambridge

George Arms, Professor of English, University of New Mexico

William Arrowsmith, University Professor, Boston University

John Arthos, Hereward T. Price University Professor of English, University of Michigan

Stuart Atkins, Professor of German, University of California (Santa Barbara)

Arra Avakian, National Association for Armenian Studies and Research

María Teresa Babin, Professor of Spanish, Graduate Center, City University of New York

James Baird, Professor of English, Connecticut College

Anna E. Balakian, Professor of Romance Languages and Comparative Literature, New York University

Linton Lomas Barrett, late Professor of Romance Languages, Washington and Lee University

Paull F. Baum, late James B. Duke Professor of English, Duke University

Glen W. Baxter, Lecturer in East Asian Languages and Civilizations, Harvard University, and Associate Director of the Harvard-Yenching Institute

Max I. Baym, Professor Emeritus of the $\mathrm{Hu}$ manities, Polytechnic Institute of Brooklyn

Monroe C. Beardsley, Professor of Philosophy, Temple University

William Beare, late Professor of Latin and onetime Pro-Vice Chancellor, University of Bristol

Joseph C. Beaver, Professor of Linguistics, Northeastern Illinois University

Richard Beck, University Professor Emeritus of Scandinavian Languages and Literatures, University of North Dakota

Robert Beloof, Professor of Rhetoric, University of California (Berkeley)

Allen R. Benham, late Professor of English, University of Washington
Aldo S. Bernardo, Professor of Romance Languages and Chairman of the Division of Humanities, State University of New York (Binghamton)

Jess B. Bessinger, Jr., Professor of English, New York University

John L. Bishop, Lecturer in East Asian Languages and Civilizations, Harvard University

Harold Bloom, Professor of English, Yale University

Morton W. Bloomfield, Arthur Kingsley Porter Professor of English, Harvard University

Arna Bontemps, late poet and writer

Smith Palmer Bovie, Professor of Classics, Rutgers University

Thomas O. Brandt, late Professor of German and Chairman of the Department of German and Russian, Colorado College

David Bromwich, Scholar of the House in American Literature, Pierson College, Yale University

Cleanth Brooks, Gray Professor of Rhetoric, Yale University

Huntington Brown, Professor Emeritus of English, University of Minnesota

Merle E. Brown, Professor of English, University of Iowa

James Camp, Associate Professor of English, Newark College of Engineering

Leonard Casper, Professor of English, Boston College

Frank M. Chambers, Professor of French, University of Arizona

Kun Chang, Professor of Oriental Languages, University of California (Berkeley)

Seymour Chatman, Professor of Rhetoric, University of California (Berkeley)

Arthur Melville Clark, Reader Emeritus in English Literature, University of Edinburgh

Dorothy Clotelle Clarke, Professor of Spanish, University of California (Berkeley)

Stanley K. Coffman, Professor and Chairman of the Department of English, Bowling Green State University

W. E. Collin, former Professor of Romance Languages, University of Western Ontario

Padraic Colum, late poet and author

J. E. Congleton, Professor Emeritus of English, Findlay College

Mercer Cook, Professor Emeritus of Romance Languages, Howard University

Procope S. Costas, Professor of Classics, Brooklyn College, City University of New York 


\section{CONTRIBUTORS}

Hardin Craig, late Professor of English, Stanford University, University of North Carolina, and University of Missouri

R. S. Crane, late Distinguished Service Professor of English, University of Chicago

John A. Crow, Professor of Spanish, University of California (Los Angeles)

István Csicsery-Rónay, Hungarian writer and critic

Jonathan D. Culler, Fellow and Director of Studies in Modern Languages, Selwyn College, University of Cambridge

A. Grove Day, Professor Emeritus of English, University of Hawaii

Paul de Man, Professor of Comparative and French Literature, Yale University

Endre De Spur, formerly, The Gypsy Lore Society

Vinton A. Dearing, Professor of English, University of California (Los Angeles)

R. J. Dorius, Professor of English, San Francisco State College

David F. Dorsey, Associate Professor of English and Afro-American Studies, Atlanta University

Fred A. Dudley, Professor Emeritus of English. Washington State University

Charles W. Dunn, Margaret Brooks Robinson Professor of Celtic Languages and Literatures and Chairman of the Department, Harvard University

Robert M. Durling, Professor of English, University of California (Santa Cruz)

John M. Echols, Professor of Linguistics and Asian Studies, Cornell University

Brian R. Elliott, Reader in Australian Literature, University of Adelaide

Robert C. Elliott, Professor of English Literature, University of California (San Diego)

Gerald F. Else, Professor of Classical Studies and Director of The Center for Coördination of Ancient and Modern Studies, University of Michigan

John J. Enck, late Professor of English, University of Wisconsin

Alfred Garwin Engstrom, Alumni Distinguished Professor of French, University of North Carolina (Chapel Hill)

Victor Erlich, Bensinger Professor of Russian Literature, Yale University

Alvin A. Eustis, Professor of French, University of California (Berkeley)

Robert O. Evans, Professor of English, University of Kentucky

Robert P. Falk, Professor of English, University of California (Los Angeles)

Leon Feraru, late Professor and Chairman of the Department of Modern Languages, Long Island University

Palamandadige Eberg Edwin Fernando, Professor of Sinhalese, University of Ceylon
Solomon Fishman, former Professor of English, University of California (Davis)

Wolfgang Bernard Fleischmann, Professor of Comparative Literature and Dean of the School of Humanities, Montclair State College

Richard Harter Fogle, University Distinguished Professor of English, University of North Carolina (Chapel Hill)

Stephen F. Fogle, late Professor of English, Adelphi Suffolk College

Zbigniew Folejewski, Professor of Slavonic Studies and Chairman, Comparative Literature, University of British Columbia

Tatiana Fotitch, Professor Emeritus of Romance Languages and Literatures, Catholic University of America

Wallace Fowlie, James B. Duke Professor of French Literature, Duke University

Jean Franco, Professor of Spanish and Comparative Literature, Stanford University

John Fraser, Professor of English, Dalhousie University

Ralph Freedman, Professor of Comparative Literature, Princeton University

Bernard J. Fridsma, Professor Emeritus of Germanic Languages, Calvin College

Albert B. Friedman, Professor of English, Claremont Graduate School

Norman Friedman, Professor of English, Queens College, City University of New York

Northrop Frye, University Professor, Massey College, University of Toronto

Joseph G. Fucilla, Professor Emeritus of Romance Languages, Northwestern University

Paul Fussell, Professor of English, Rutgers University

Naomi Garrett, Professor of Romance Languages, West Virginia State College

Carolyn F. Gerald, Associate Professor of Black Literature, Atlanta University

Robert J. Getty, late Paddison Professor of Classics, University of North Carolina (Chapel Hill)

Pierre Gilbert, Professor of the History of Art, Université Libre de Bruxelles

G. Giovannini, Professor of English, Catholic University of America

John F. Goins, Professor of Anthropology, University of California (Riverside)

Ulrich K. Goldsmith, Professor of German and Comparative Literature, University of Colorado

Lewis H. Gordon, Professor of Italian and French, Brown University

Bernard Groom, former Professor of English, McMaster University

Fabian Gudas, Professor of English, Louisiana State University 


\section{CONTRIBUTORS}

Hans G, Güterbock, Tiffany and Margaret Blake Distinguished Service Professor of Hittitology, University of Chicago

Theodore Johannes Haarhof, Emeritus Professor of Classics, University of the Witwatersrand, Johannesburg

Vernon Hall, Jr., Professor of Comparative Literature, University of Wisconsin (Madison)

Talat S. Halman, Lecturer in Turkish, Princeton University

O. B. Hardison, Jr., Director, The Folger Shakespeare Library

Jacques Hardré, Kenan Professor of French and Chairman of the Department of Romance Languages, University of North Carolina (Chapel Hill)

William E. Harkins, Professor of Slavic Lan. guages, Columbia University

Lyndon Harries, Professor of African Languages and Literature, University of Wisconsin (Madison)

Sylvia C. Harris, Lecturer in German, Birkbeck College, University of London

Samuel Hazo, Professor of Literature, Duquesne University

George T. Hemphill, Professor of English, University of Connecticut

Hanford M. Henderson, formerly, American Academy, Rome

Marvin T. Herrick, late Professor of English, University of Illinois

Daniel G. Hoffman, Professor of English, University of Pennsylvania

John Hollander, Professor of English, Hunter College, City University of New York

C. Hugh Holman, Kenan Professor of English, University of North Carolina (Chapel Hill)

Urban T. Holmes, Jr., Kenan Professor of Romance Languages, University of North Carolina (Chapel Hill)

Roger A. Hornsby, Professor and Chairman of the Department of Classics, University of Iowa

Leo Hughes, Professor of English, University of Texas

Gloria T. Hull, Assistant Professor of English, University of Delaware

W.T.H. Jackson, Professor of German and History, Columbia University

Vera Javarek, former Lecturer in Serbo-Croatian Language and Literature, University of London

Douglas Johnson, Assistant Professor of Black Literature, Federal City College

James William Johnson, Professor of English, University of Rochester

Charles W. Jones, Professor of English, University of California (Berkeley)

Michael K. Joseph, Professor in English, Auckland University, N. Z.
Sholom J. Kahn, Assistant Professor of English, Hebrew University, Jerusalem

John D. Kendall, formerly, School of Library Science, University of Minnesota

Hugh Kenner, Professor of English Literature, Johns Hopkins University

Kevin Kerrane, Associate Professor of English, University of Delaware

Thomas A. Kirby, Professor and Head of the Department of English, Louisiana State University

Charles A. Knudson, Professor of French, University of Illinois

June Q. Koch, Assistant Professor of English, Bryn Mawr College

Miriam Koshland-Joel, writer and translator

Manfred Kridl, late Adam Mickiewicz Professor of Polish Studies, Columbia University

Murray Krieger, University Professor of English, University of California (Irvine)

John R. Krueger, Professor of Uralic and Altaic Studies, Indiana University

James Craig La Drière, Professor of Comparative Literature, Harvard University

Stephen A. Larrabee, author and critic

Sally N. Lawall, Professor and Chairman of the Department of Comparative Literature, University of Massachusetts

Laurence D. Lerner, Professor of English, University of Sussex, England

Samuel R. Levin, Professor of English, Graduate Center, City University of New York

John L. Lievsay, James B. Duke Professor of English, Duke University

Herbert Lindenberger, Avalon Professor of $\mathbf{H u}$ manities in Comparative Literature and English and Chairman, Department of Comparative Literature, Stanford University

René Felix Lissens, Professor of Dutch Literature and European Literatures, Universitaire Faculteiten, St.-Ignatius, Antwerp

D. Myrddin Lloyd, Keeper of Printed Books, National Library of Scotland

Edgar Lohner, Professor and Chairman of the Department of German, Stanford University

Richard A. Long, Professor of English and Director, Center for African and African-American Studies, Atlanta University

Albert B. Lord, Arthur Kingsley Porter Professor of Slavic and Comparative Literature, Harvard University

Katharine Luomala, Professor of Anthropology, University of Hawaii

Sverre Lyngstad, Professor of English, Newark College of Engineering

Frederick P. W. McDowell, Professor of English, University of Iowa

John MacInnes, Lecturer in Scottish Studies, University of Edinburgh

Clarence A. Manning, former Associate Professor of Slavic Languages, Columbia University 


\section{CONTRIBUTORS}

Vladimir Markov, Professor of Slavic Languages, University of California (Los Angeles)

Robert Marsh, Professor of English, University of Chicago

Wallace Martin, Professor of English, University of Toledo

David I. Masson, Librarian in Charge of Brotherton Collection, University of Leeds Library

William Kleesman Matthews, late Professor of Russian Language and Literature and Head of the Department of Language and Literature at the School of Slavonic and East European Studies, University of London

Rigo Mignani, Professor of Romance Languages, State University of New York (Binghamton)

Louis T. Milic, Professor of English, Cleveland State University

Elizabeth Maxfield Miller, former Instructor in French, Concord Academy

Earl Miner, Professor of English, Princeton University

Luis Monguib, Professor of Spanish, University of California (Berkeley)

Stephen L. Mooney, late Professor of English, University of Tennessee

Bayard Quincy Morgan, late Professor of German, Stanford University

Wesley Morris, Associate Professor of English, Rice University

John M. Munro, Professor of English, American University of Beirut

Robert D. Murray, Jr., Associate Professor of Classics, Princeton University

George Nakashidse, former Lecturer in Georgian History and Literature, Columbia University

Lowry Nelson, Jr., Professor of Comparative Literature, Yale University

William Van O'Connor, late Professor and Chairman of the Department of English, University of California (Davis)

John B. Olli, Professor Emeritus of Germanic and Slavic Languages, City College, City University of New York

Ants Oras, Professor of English, University of Florida

G.N.G. Orsini, Professor and Chairman of the Department of Comparative Literature, University of Wisconsin (Madison)

Kostas Ostrauskas, Lithuanian dramatist, literary historian, and musicologist

Lucy B. Palache, editorial research assistant

Douglass S. Parker, Professor of Classics, University of Texas

Richard A. Parker, Wilbour Professor of Egyptology, Brown University

John P. Pauls, Professor of Russian Language and Literature, University of Cincinnati

Hla Pe, Professor of Burmese, School of Oriental and African Studies, University of London
Laurence Perrine, Professor of English, Southern Methodist University

Robert H. Pfeiffer, late Hancock Professor of Hebrew and Other Oriental Languages, Harvard University

Allen W. Phillips, Professor of Spanish, University of Texas

Seymour M. Pitcher, Professor of English and Comparative Literature, State University of New York (Binghamton)

Alex Preminger, Associate Professor, Brooklyn College Library, City University of New York

Frederick James Edward Raby, late Fellow of the British Academy. Honorary Fellow, Jesus College, University of Cambridge

V. Raghavan, Professor Emeritus and former Head of the Department of Sanskrit, University of Madras

Paul Ramsey, Alumni Distinguished Service Professor of English, University of Tennessee (Chattanooga)

Joseph Remenyi, late Professor of Comparative Literature, Western Reserve University

Elias L. Rivers, Professor of Spanish and Chairman of the Department of Romance Languages, Johns Hopkins University

James K. Robinson, Professor and Head of the Department of English, University of Cincinnati

Brewster Rogerson, Professor of English, Kansas State University

George Brandon Saul, Professor of English, University of Connecticut

Aldo Scaglione, W. R. Kenan Professor of Romance Languages and Comparative Literature, University of North Carolina (Chapel Hill)

Bernard N. Schilling, Trevor Professor of English and Comparative Literature, University of Rochester

H. Stefan Schultz, Professor of German, University of Chicago

Alexander H. Schutz, late Professor of Romance Languages, Ohio State University

Christoph E. Schweitzer, Professor and Chairman of the Department of Germanic Languages and Literatures, University of North Carolina (Chapel Hill)

A. Lytton Sells, Professor Emeritus of French and Italian, Indiana University

R. B. Serjeant, Sir Thomas Adams's Professor of Modern Arabic, University of Cambridge

Vsevoled Setchkarev, Curt Hugo Reisinger Professor of Slavic Languages and Literatures, Harvard University

Lawrence A. Sharpe, Associate Professor of Spanish and Portuguese, University of North Carolina (Chapel Hill)

Albert Thompson Shaw, former Director of Music and Art Master, The Royal Grammar School, Worcester, England 


\section{CONTRIBUTORS}

Eisig Silberschlag, Professor of Literature and Dean, Hebrew Teachers College, Brookline

Isidore Silver, Rosa May Distinguished Professor in the Humanities, Washington University

John I. Simon, drama and film critic

A. Neil Skinner, Professor of African Languages and Literature, University of Wisconsin (Madison)

A.J.M. Smith, Professor Emeritus of English, Michigan State University

Barbara Herrnstein Smith, Professor of Literature, Bennington College

Robert W. Stallman, Professor of English, University of Connecticut

Edward Stankiewicz, Professor of Slavic Languages and Linguistics, Yale University

Martin Steinmann, Jr., Professor of English, University of Minnesota

Stephen Stepanchev, Professor of English, Queens College, City University of New York

Roy Arthur Swanson, Professor of Classics and Comparative Literature and Chairman of the Department of Comparative Literature, University of Wisconsin (Milwaukee)

Kiril Taranovski, Professor of Slavic Languages and Literatures, Harvard University

William Thalbitzer, late Professor of Eskimo Language and Culture, University of Copenhagen

John Thompson, Professor of English, State University of New York (Stony Brook)

Robert D. Thornton, Professor of English and Chairman of the Department of English and World Literature, State University of New York (New Paltz)

Ernst S. Trümpler, Instructor, Kantonsschule Schaffhausen, Switzerland

C. A. Trypanis, former Bywater and Sotheby Professor of Byzantine and Modern Greek Languages and Literatures, University of $\mathrm{Ox}$ ford

Louis Untermeyer, poet, anthologist, and editor

Gustave Vanwelkenhuyzen, Académie Royale de langue et de Littérature Françaises, Brussels
V. H. Viglielmo, Professor of Japanese, University of Hawaii

Frank J. Warnke, Professor of English and Chairman, Comparative Literature, University of Washington

Weber-Perret, Swiss author, journalist, and educator

Kurt Weinberg, Professor of Foreign Languages and Comparative Literature, University of Rochester

Uriel Weinreich, late Professor of Yiddish Language, Literature, and Culture on the Atran Chair, and Chairman of the Department of Linguistics, Columbia University

Ulrich Weisstein, Professor of German and Comparative Literature, Indiana University

Henry W. Wells, Curator Emeritus, Brander Matthews Dramatic Museum, Columbia University. Former Professor of English, Columbia University

George Whalley, Professor and Head of the Department of English, Queen's University

Philip Wheelwright, late Professor of Philosophy, University of California (Riverside)

Harold Whitehall, Professor Emeritus of English and Linguistics, Indiana University

William Willeford, Associate Professor of English and Comparative Literature, University of Washington

William Carlos Williams, late poet and author Sir Richard Olaf Winstedt, former Reader in Malay, University of London

A.S.P. Woodhouse, late Professor of English, University of Toronto

Mabel P. Worthington, Professor of English, Temple University

Stephen Wright, formerly, Haile Selassie I University, Addis Ababa

Paul M. Zall, Professor of English, California State University

Henri de Ziègler, former President, University of Geneva

Lawrence J. Zillman, Professor of English, University of Washington 